\title{
EVALUATION OF INDIVIDUAL SOCIAL RESPONSIBILITY LEVEL OF UNIVERSITY STUDENTS FOR SPORT AND OTHER DIFFERENT VARIABLES ${ }^{1}$
}

\section{ÜNIVERSITTE ÖĞRENCILLERINIIN BİREYSEL SOSYAL SORUMLULUK DÜZEYLERININ SPOR VE FARKLI DEĞISTKENLER AÇISINDAN INCELENMESI}

\author{
Gökhan BAYRAKTAR ${ }^{1}$, Erdoğan TOZOĞLU ${ }^{2}$, Öner GÜLBAHÇE ${ }^{2}$, \\ M. Ertuğrul ÖZTÜRK ${ }^{2}$ Arzu GÜLBAHÇE ${ }^{2}$ \\ ${ }^{1}$ Ăgrı İbrahim Çeçen University. Physical Education and Sport High School, A Ărı / Turkey \\ ${ }^{2}$ Ataturk University, Kazım Karabekir Education Faculty, Department of Physical Education and Sports, \\ Erzurum / Turkey
}

Öz: Araştırmanın amacı, üniversite öğrencilerinin bireysel sosyal sorumluluk düzeylerinin belirlenmesi ve kişisel özelliklerine göre bireysel sosyal sorumluluk düzeyleri arasındaki farklılıkların incelenmesidir. Araştırma grubunu, 2014-2015 eğitim ve öğretim yılında Erzurum Atatürk Üniversitesinde öğrenim gören, 182'si kadın 255'i erkek olmak üzere toplam 437 öğrenci oluşturmaktadır. Araştırmada veri toplama aracı olarak; 33 maddelik 'Bireysel Sosyal Sorumluluk Ölçeği (Eraslan, 2011)' kullanılmıştır. İlgili ölçek, 5'li Likert Skalası tipindedir. Elde edilen bulgulara göre; üniversite öğrencilerinin bireysel sosyal sorumluluk düzeyleri ile spor yapma durumu, spor yapma süresi ve haftalık spor yapma süreleri bakımından değerlendirildiğinde anlamlı sonuçlara ulaşıldığı ve spor yapan öğrencilerin bireysel sorumluluk düzeylerinin yüksek olduğu tespit edilmiştir. Cinsiyet, yaş, aile yapısı, kişisel aylık gelir ve yapmış olduğu spor türü değişkenleri bakımından değerlendirildiğinde ise anlamlı sonuçlara ulaşılmadığı görülmektedir. Öğrencilerin toplumsal sorunlara ve kişisel sorunlara yönelik bilinçlilik düzeylerinin yüksek olması toplum ve birey açısından olumlu sonuçlar sağlaması düşünülmektedir. Çıkan sonuçlar incelendiğinde, sporun bireylerde sosyal sorumluluk üzerinde olumlu etkisinin olması, gençlerinin spor yapması için yönlendirilmesi ve imkânların sağlanması önem arz ederek, çalışmamızın da önerisi olarak ifade edilebilir.

Anahtar Kelimeler: Bireysel Sosyal Sorumluluk, Üniversite Öğrencileri, Spor
Abstract: The aim of the present study is to determine individual social responsibility levels of university students and to evaluate differences between them depending on their individual characteristics. Study group consists of 437 subjects (182 females and 255 males) among the students attending Ataturk University in 2014-2015 education term. Individual Social Responsibility Scale (Eraslan, 2011) with 33 items was used as the data gathering tool. Scale in question is in the 5 - grade Likert Scale. It was determined from the results that relationship between individual social responsibility levels of university student sand the state of performing sportive activities, time length of sportive activities and time length of weekly sportive activities was significant and individual social responsibility levels of sport playing students were higher than others. Relationship between individual social responsibility levels and gender, age, family structure, monthly income and type of sport was found to be insignificant. High awareness level of students towards social and individual problems is thought to cause positive results for society and individuals. It may be stated when the results of the study are evaluated that sports have positive effects on individual social responsibility and it is important that the youth should be directed to sport by providing them opportunities.

Key Words: Individual Social Responsibility, University Students, Sport

Doi: $10.17363 /$ SSTB.20161816491

(1) Corresponding Author: Gökhan BAYRAKTAR, Ăgrı İbrahim Çeçen University, Physical Education and Sport High School, Ăgrı / Turkey gokbayraktar@gmail.com Received: 28.12.2015 Accepted: 11.03.2016 Type ofarticle (Research -Application) Conflict of Interest: None / "None of Ethics Committee" 


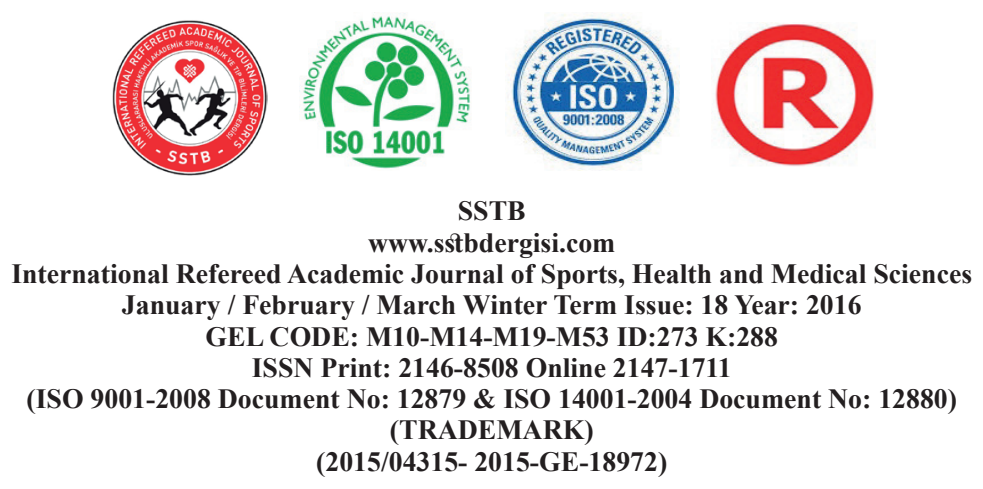

\section{Introduction}

Humans, as a social creature, have different responsibilities and duties from the moment they are born to the end of their lives. Some of these responsibilities are for the individual himself and some of them are for the social environment he lives. As a member of the society, a sense of responsibility is of higher importance that the individual should fulfill his/her tasks towards the society, s/he intends to be a beneficial for both himself/herself and the society (Yontar and Yurtal, 2009: 146).

It can be seen that there are different definitions about the responsibility in the literature that is developed through practicing and repeating like all the other skills the individual learns through his/her life. Dodurgalı (2010:191) defines responsibility as the human gains an individual personality and he comprehends his tasks towards himself and the society and develops appropriate behaviors, and Cüceloğlu (2002: 198) defines responsibility as the individual is ready to account for the events he consider them within his limits.

Responsibility is the obligation that the individual should fulfill the duties he is accounted for himself and others at the right time. It also means that the individual takes on the effects of his event on others, respects the rights of the others and embraces the results of his own behaviors. ${ }^{1}$

Responsibility is divided into two as social and individual responsibility. Individual responsibility is that the individual is aware of the attitudes and the behaviors that the society expect from him and fulfills these duties both for the society and himself. People who have individual responsibilities are the people who can use their own resources, are selfsufficient, makes their own decisions, takes responsibility of their actions, act independently, meet their own needs without spoiling the rights of others, can criticize themselves, are prone to collaboration, can use time efficiently. And the social responsibility is that the individual act in a way that will develop and protect the interests of the society as well as his own interests. People who have social responsibility are the people who respect the nature and the environment, are sensitive to social problems, have organizational citizenship and moral values. Individuals with higher sense of responsibility complete the tasks and duties they take on even they are very difficult and face the consequences of their actions. These individuals are generally the individuals who are chosen by others to complete a task when there is a task to be done (http://webportal.robcol.k12.tr ; Nelson ve Low, 2004: 84) and these individuals are

1 (http://webportal.robcol.k12.tr) 


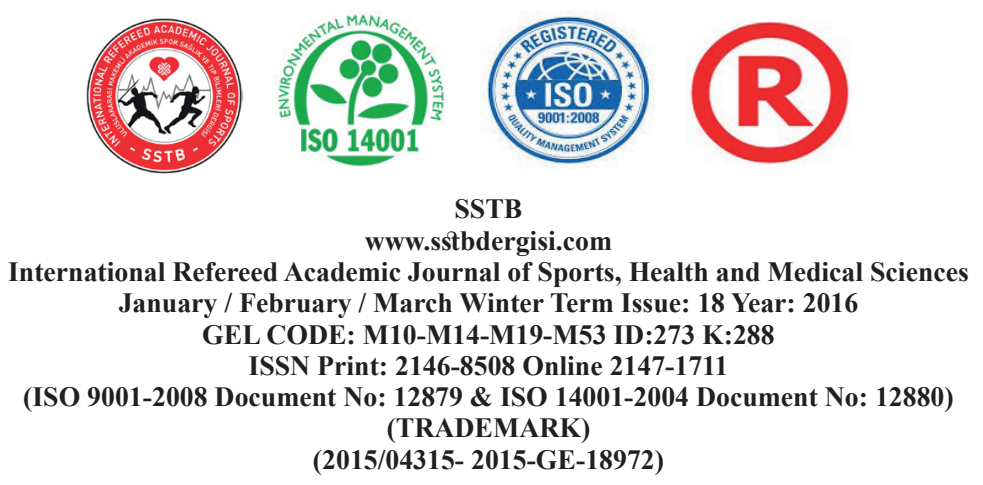

hardworking and they are a good parent and a good neighbor (Lucker, 1994: 15).

Whether it is an individual or a social responsibility, there are some factors affecting the development of responsibility. Among these; family, school, traditions-customs and cults are the most important factors that affect the development of responsibility.

For a child to have sense of responsibility, he needs to be grown up in an environment where he can take responsibility. If the child is not given the right to choose and he is not held responsible for consequences of the actions he has done, sense of responsibility in the child will not develop. Thus, the child will not get mature as he is not allowed to express his own ideas and has the opportunity to decide his own actions. The parents should lay a burden to their children appropriate to their ages and physical developments and should support them in discharging these responsibilities (Durmuş, 2006: 145).

For the parents, that the children have responsibility becomes at their agenda when the children start school. When a child who has been given responsibility since childhood starts school, he does not have any problems in doing his homework on time, studying, obeying the rules in the school. The parents should be better role models to their children in raising children who has the sense of responsibility.

The school is responsible for correcting different deficiencies and mistakes originating from the family. The school and the teachers have tremendous responsibilities. It is very important that the children participate in different activities to develop successful identity instead of unsuccessful identity in the school. The children need to feel that they are loved and valued. If they do not meet these needs in the school from their teachers in the schools, they will develop unsuccessful identity (Hayta Önal, 2005: 39).

Each individual learns to respect to the culture of the society he lives in and the values related to this culture, social norms that the society has formed. Individuals constituting the society are obliged to act and organize their lives according to these social norms, know these social norms, and fulfill the enforcement of these norms. Social norms, that is traditions and customs, give some responsibilities to the individuals and requires them to fulfill the requirements. In this context, people with strong personality and sense of responsibility become individuals who blend with the values of the society and experience the basic elements like religion, language, traditions, customs, history etc. which are fields of the culture, and can understand the 


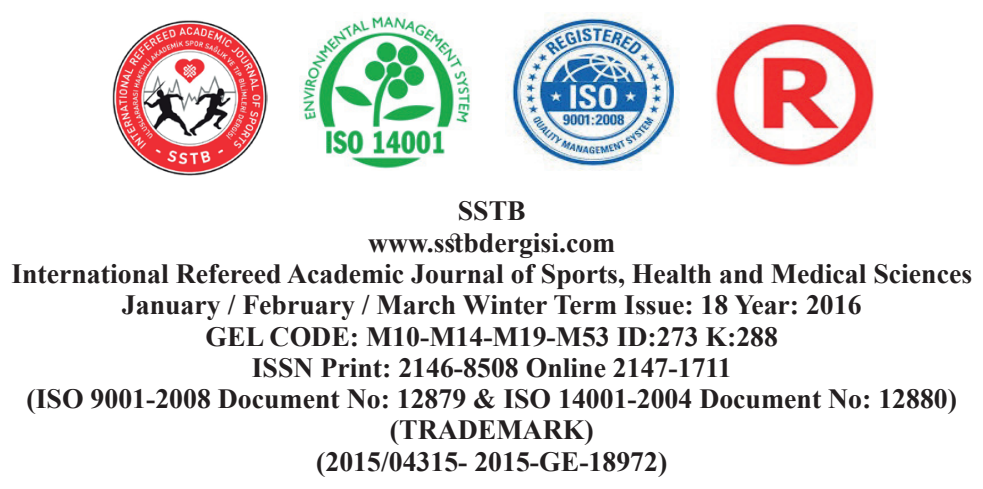

internal relation of these values with one another (Tozlu, 1991: 137).

It is thought that doing sports, engaging in sportive activities is another factor which affects the individual and social responsibility in addition to family, school and traditions. It is seen that sport can play a role as an instrument in developing and spreading particularly social responsibility in today's world. Prompting sport as a correct instrument towards social responsibility activities is considered to be an important opportunity for both the organizations related to sports and for contributing to the society (Smith and Westerbeeck, 2007). With reference to the fact that particularly individual sports can be effective in developing individual responsibility and team sports can be effective in developing social responsibility in addition to the contributions of the sports to physical, emotional, psychologic and social developments, it is aimed in this study to analyze the individual and social responsibility levels of the undergraduates who do sports and who don't in terms of different variables.

\section{Method}

In this study, descriptive method is used in order to reveal a present situation.

\section{Research Group}

The work group of the study consists of 437 students, 182 females and 255 males, who get educated in different departments of Kazım Karabekir Faculty of Education, University of Erzurum Atatürk in 2014-2015 academic years.

\section{Data Collecting Instruments}

"Individual-Social Responsibility Questionnaire" is used to collect data in the study.

Personal Information Form: "Personal Information Form" developed by the researcher includes questions related to independent variables of gender, age, family structure, personal monthly income and doing sports in order to collect data about the students who get educated in subject university.

\section{The Questionnaire}

"Individual Responsibility Questionnaire" developed by Eraslan to evaluate attitudes towards individual and social responsibility includes 33 items. The instrument developed to measure the sense of individual responsibility levels of the university students is a 5-likety type scale. The highest score that can be got from the scale is 225 , and the lowest one is 45. Higher scores indicate high level of individual responsibility.

\section{Findings}

In this section, findings obtained through the study and interpretations related to these findings are presented. Table 1 and 2 indicate the frequency distributions related to the de- 
www.sstbdergisi.com

International Refereed Academic Journal of Sports, Health and Medical Sciences

January / February / March Winter Term Issue: 18 Year: 2016

GEL CODE: M10-M14-M19-M53 ID:273 K:288

ISSN Print: 2146-8508 Online 2147-1711

(ISO 9001-2008 Document No: 12879 \& ISO 14001-2004 Document No: 12880)

(TRADEMARK)

(2015/04315- 2015-GE-18972)

mographic characteristics and doing sports situations of the university students. In the study, $t$ test is used to compare gender and scores from the individual-social responsibility questionnaire, doing sports situations and the type of the sports variables, and the statistical results are indicated in Table 3, 7 and 8. ANOVA variance analysis test is used in the comparison of the variables of age, family structure, personal monthly income, doing sport time, and weekly doing sport span with the values obtained from the individualsocial responsibility questionnaire, and the statistical results are indicated in Table 4, 5, 6, 9 and 10 .

Table 1. The Distribution of the Demographic Characteristics of the Students

\begin{tabular}{l|l|c|c}
\hline \multirow{4}{*}{ Gender } & \multicolumn{1}{|c|}{ Variable } & $\begin{array}{c}\text { Number } \\
\text { (N) }\end{array}$ & Ratio \\
\hline \multirow{4}{*}{ Age } & Famele & 182 & 41,6 \\
\cline { 2 - 4 } & Male & 255 & 58,4 \\
\cline { 2 - 4 } & Total & 437 & 100,0 \\
\hline \multirow{4}{*}{ Family Structure } & 20 and below & 101 & 23,1 \\
\cline { 2 - 4 } & Between 21-24 & 265 & 60,6 \\
\cline { 2 - 4 } & 25 and above & 71 & 16,2 \\
\hline \multirow{4}{*}{$\begin{array}{l}\text { Personal Monthly Income } \\
\text { Yararlanma }\end{array}$} & Nuclear Family & 317 & 72,5 \\
\cline { 2 - 4 } & Extended Family & 106 & 24,3 \\
\cline { 2 - 5 } & Broken Family & 14 & 3,2 \\
\cline { 2 - 5 } & Between 301-600 tl & 182 & 41,6 \\
\cline { 2 - 5 } & Between 601-1200 tl & 85 & 19,5 \\
\cline { 2 - 5 } & 1201 tl and above & 34 & 7,8 \\
\hline
\end{tabular}




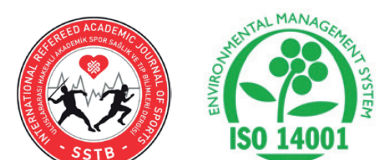

SSTB

www.sstbdergisi.com

International Refereed Academic Journal of Sports, Health and Medical Sciences

January / February / March Winter Term Issue: 18 Year: 2016

GEL CODE: M10-M14-M19-M53 ID:273 K:288

ISSN Print: 2146-8508 Online 2147-1711

(ISO 9001-2008 Document No: 12879 \& ISO 14001-2004 Document No: 12880)

(TRADEMARK)

(2015/04315- 2015-GE-18972)

Table 2. The Distribution of the Student's Doing Sports Situation

\begin{tabular}{|c|c|c|c|}
\hline & Variable & $\begin{array}{l}\text { Number } \\
\text { (N) }\end{array}$ & Ratio \\
\hline \multirow[t]{3}{*}{ Doing Sport Situation } & Doing Sports & 248 & 56,8 \\
\hline & Not Doing Sports & 189 & 43,2 \\
\hline & Total & 437 & 100,0 \\
\hline \multirow{3}{*}{$\begin{array}{l}\text { What kind of sports do } \\
\text { you do? }\end{array}$} & Individual & 149 & 34,1 \\
\hline & Team Sports & 99 & 22,7 \\
\hline & Not doing sports & 189 & 43,2 \\
\hline \multirow{4}{*}{$\begin{array}{l}\text { How long have you been } \\
\text { doing sports? }\end{array}$} & 1 year and below & 33 & 7,6 \\
\hline & Between 2-4 years & 71 & 16,2 \\
\hline & 5 years and above & 144 & 33,0 \\
\hline & Not doing sports & 189 & 43,2 \\
\hline \multirow{2}{*}{$\begin{array}{l}\text { How many hours do you } \\
\text { do sports in a week? }\end{array}$} & 1 hour and below & 60 & 13,7 \\
\hline & Between 2-4 hours & 104 & 23,8 \\
\hline \multirow{2}{*}{$\begin{array}{l}\text { Spor Tesislerinden } \\
\text { Yararlanma }\end{array}$} & 5 hours and above & 84 & 19,2 \\
\hline & Not doing sports & 189 & 43,2 \\
\hline
\end{tabular}

Table 3. The Average of the Scores of the Male and Female Students From the Individual-Social Responsibility Questionnaire and Values of the Differences Between Standard Deviation and Averages

\begin{tabular}{c|c|c|c|c|c}
\hline Gender & N & X & Ss & t & p \\
\cline { 1 - 5 } Female & 182 & 149,01 & 17,613 & 1,305 & \multirow{2}{*}{, 406} \\
\hline Male & 255 & 148,00 & 18,828 & 1,179 & \\
\hline
\end{tabular}

On analyzing the Table 3 , it can be seen that there is no significant differences in p:0,05 level between the scores of the male and female students from the individual-social responsibility questionnaire. In addition, it is determined that the scores of the female students are higher than the scores of the male students in terms of the average scores from the individual responsibility questionnaire. 
www.sstbdergisi.com

International Refereed Academic Journal of Sports, Health and Medical Sciences

January / February / March Winter Term Issue: 18 Year: 2016

GEL CODE: M10-M14-M19-M53 ID:273 K:288

ISSN Print: 2146-8508 Online 2147-1711

(ISO 9001-2008 Document No: 12879 \& ISO 14001-2004 Document No: 12880)

(TRADEMARK)

(2015/04315- 2015-GE-18972)

Table 4. The Averages and Standard Deviation Values of the Scores of the Students in Different Age Groups from Individual-Social Responsibility Questionnaire

\begin{tabular}{l|c|c|c|c|c|c}
\hline \multicolumn{1}{c|}{ Age } & N & X & Ss & F & P & Fark \\
\cline { 1 - 4 } 20 year-old and below & 101 & 147,29 & 17,790 & & & \\
\cline { 1 - 4 } Between 21-24 year-old & 265 & 148,96 & 18,750 & \multirow{2}{*}{, 326} & \multirow{2}{*}{, 722} & ------ \\
\cline { 1 - 5 } 25 year-old and above & 71 & 148,01 & 17,572 & & & \\
\cline { 1 - 5 } Total & 437 & 148,42 & 18,318 & & & \\
\hline
\end{tabular}

When Table 4 is analyzed, it can be seen that vidual-social responsibility questionnaire of there is no significant difference at p: 0,05 the students in different age groups.

level between the scores got from the indi-

Table 5. The Average and Standard Deviation of the Scores of the Students Who Have Different Family Structure

\begin{tabular}{|c|c|c|c|c|c|c|}
\hline Family Structure & $\mathbf{N}$ & $\mathbf{X}$ & Ss & $\mathbf{F}$ & $\mathbf{P}$ & Difference \\
\hline Nuclear Family & 317 & 148,09 & 17,834 & \multirow{4}{*}{, 255} & \multirow{4}{*}{, 775} & \multirow{4}{*}{----- } \\
\hline Extended Family & 106 & 149,09 & 19,423 & & & \\
\hline Broken Family & 14 & 150,93 & 21,485 & & & \\
\hline Total & 437 & 148,42 & 18,318 & & & \\
\hline
\end{tabular}

On analyzing Table 5, it is seen that there is no significant difference at p:0,05 level between the scores got from the individual- social responsibility questionnaire of the students who have different family structure. 


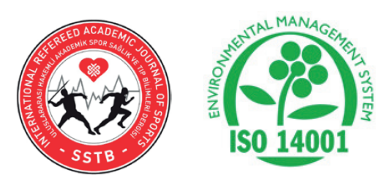

SSTB

www.sstbdergisi.com

International Refereed Academic Journal of Sports, Health and Medical Sciences

January / February / March Winter Term Issue: 18 Year: 2016

GEL CODE: M10-M14-M19-M53 ID:273 K:288

ISSN Print: 2146-8508 Online 2147-1711

(ISO 9001-2008 Document No: 12879 \& ISO 14001-2004 Document No: 12880)

(TRADEMARK)

(2015/04315- 2015-GE-18972)

Table 6. The Average and Standard Deviation of the Scores of the Students Who Have Different Personal Monthly Income

\begin{tabular}{|c|c|c|c|c|c|c|}
\hline $\begin{array}{l}\text { Personal Monthly } \\
\text { Income }\end{array}$ & $\mathbf{N}$ & $\mathbf{X}$ & Ss & $\mathbf{F}$ & $\mathbf{P}$ & Difference \\
\hline 300 tl and below & 136 & 146,90 & 17,202 & \multirow{5}{*}{,650 } & \multirow{5}{*}{, 583} & \multirow{5}{*}{------ } \\
\hline Between 301-600 tl & 182 & 148,46 & 19,398 & & & \\
\hline Between 601-1200 tl & 85 & 149,99 & 17,207 & & & \\
\hline 1201 tl and above & 34 & 150,38 & 19,628 & & & \\
\hline Total & 437 & 148,42 & 18,318 & & & \\
\hline
\end{tabular}

When Table 6 is analyzed, it is seen that there social responsibility questionnaire of the stuis no significant difference at p: 0, 05 level dents who have different personal monthly between the scores got from the individual- income.

Table 7. The Averages and Standard Deviation and t Values of the Differences Among the Averages of the Students who do Sports and the Students who Don't

\begin{tabular}{l|c|c|c|c|c}
\hline \multicolumn{1}{|c|}{ Gender } & N & X & Ss & t & p \\
\hline Doing Sports & 248 & 151,16 & 18,157 & 1,152 & \multirow{2}{*}{, 000} \\
\cline { 1 - 4 } Not Doing Sports & 189 & 144,83 & 17,950 & 1,305 & \\
\hline
\end{tabular}

On analyzing Table 7, it can be seen that there are significant differences at p:0,05 level between the scores got from the individualsocial responsibility questionnaire of the students doing sports and the students not do- ing sports. It is determined that the average scores of the students doing sports from the individual-social responsibility questionnaire is higher than those of the students not doing sports.

Table 8. The Averages and Standard Deviation and $t$ Values of the Differences of the Averages of the Students From the Individual-Social Responsibility Questionnaire According to the Type of the Sports They Do

\begin{tabular}{l|c|c|c|c|c}
\hline Type of the Sport & $\mathbf{N}$ & $\mathbf{X}$ & $\mathbf{S s}$ & $\mathbf{t}$ & $\mathbf{p}$ \\
\hline Individual & 149 & 151,10 & 18,858 & 1,544 & \multirow{2}{*}{, 416} \\
\cline { 1 - 5 } Team & 99 & 151,24 & 17,141 & 1,722 & \\
\hline
\end{tabular}




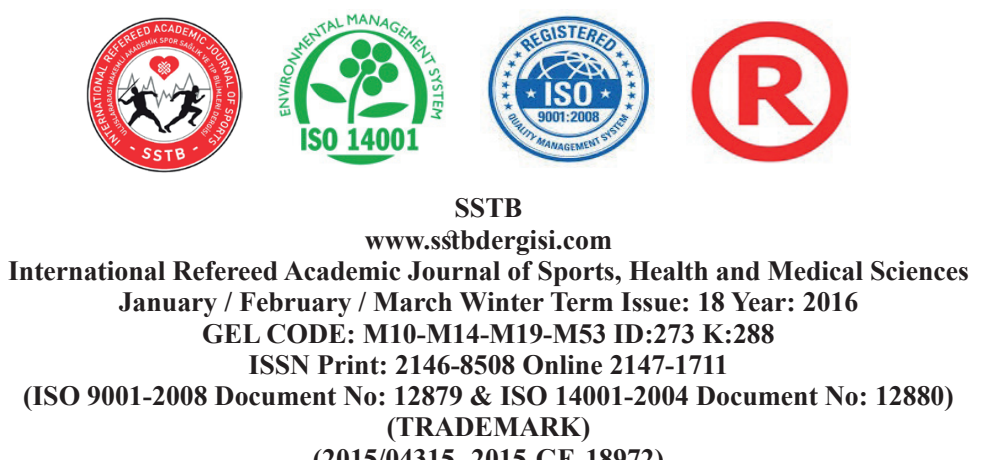

(2015/04315- 2015-GE-18972)

On analyzing Table 8 , it is seen that there is no significant difference at p:0,05 level between the scores got from the individual-

Table 9. The Average and Standard Deviation of the Scores of the Students According to the Sport Span

\begin{tabular}{|c|c|c|c|c|c|c|}
\hline Sport Span & $\mathbf{N}$ & $\mathbf{X}$ & Ss & $\mathbf{F}$ & $\mathbf{P}$ & Difference \\
\hline 1 year and below & 33 & 148,03 & 18,647 & \multirow{5}{*}{4,870} & \multirow{5}{*}{, 002} & \multirow{5}{*}{$4-2,3$} \\
\hline Between 2-4 years & 71 & 150,62 & 17,768 & & & \\
\hline 5 years and above & 144 & 152,14 & 18,267 & & & \\
\hline Not doing sports & 189 & 144,83 & 17,950 & & & \\
\hline Total & 437 & 148,42 & 18,318 & & & \\
\hline
\end{tabular}

On analyzing Table 9, it can be seen that there are significant differences at p:0,05 level between the scores got from the individualsocial responsibility questionnaire and the sports span of the students. It is determined

Table 10. The Averages and Standard Deviation Values of the Scores of the Students from Individual-Social Responsibility Questionnaire According to the Weekly Sport Span

\begin{tabular}{|c|c|c|c|c|c|c|}
\hline Weekly Sport Span & $\mathbf{N}$ & $\mathbf{X}$ & Ss & $\mathbf{F}$ & $\mathbf{P}$ & Difference \\
\hline 1 hour and below & 60 & 150,85 & 17,508 & \multirow{5}{*}{4,818} & \multirow{5}{*}{,003 } & \multirow{5}{*}{$4-1,2,3$} \\
\hline Between 2-4 hours & 104 & 149,90 & 17,517 & & & \\
\hline 5 hours and above & 84 & 152,93 & 19,421 & & & \\
\hline Not doing sports & 189 & 144,83 & 17,950 & & & \\
\hline Total & 437 & 148,42 & 18,318 & & & \\
\hline
\end{tabular}

On analyzing Table 10, it can be seen that there are significant differences at p:0,05 level between the scores got from the individual-social responsibility questionnaire and the that the average scores of the students not doing sports are lower than those of the students who do sports for between 2-4 years and 5 years and above.

social responsibility questionnaire of the students who do individual and team sports. 


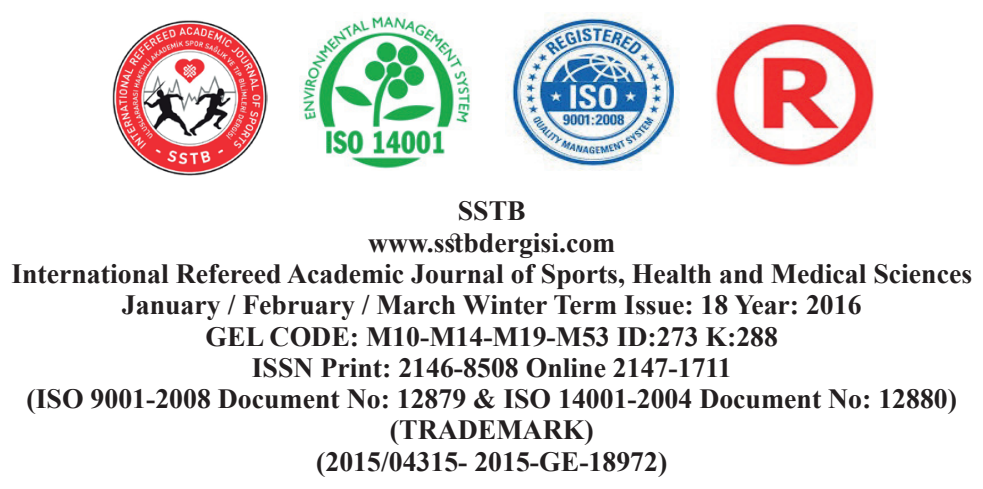

students who do sports weekly for different hours.

\section{DISCUSSION and CONCLUSION}

In the study, the relations of the individualsocial responsibility levels of 437 undergraduates, 182 females and 255 males, with different variables are analyzed. As a result of the study, the relations between the individual-social responsibility levels of the undergraduates and different variables have been analyzed and evaluations have been done according to the obtained findings.

As a result of the conducted analyses, it is seen that there is no significant difference at p:0,05 level on analyzing the $t$ values of the difference of the scores and average and the standard deviation of the scores from the individual-social responsibility scale of the male and female undergraduates. Even though there is no significant difference, it has been determined that the social responsibility levels of the female students are numerically higher than those of the male students. In the study conducted by Özalp et al. (2008), it was determined that the social responsibility perception levels of the female students are higher than those of the male students.

It is seen that there is no significant difference at $p: 0,05$ level between the scores of the students in terms of different age group, dif- ferent family structure and different monthly income variables.

It is seen that there is no significant difference at p:0,05 level on analyzing the standard deviation and averages of the scores got from individual-social responsibility scale of the students and the $t$ values of the differences among the averages in terms of doing sports variable. It has been determined that the average score of the students who do sports are higher than those of the students who do not do sports. Güven (2006) stated that engaging in sportive activities develop the senses of helping, working together, respecting other members of the group and formation of the game in children and young. Based on the related results, doing sports reveals the necessity of individual responsibility in both individual and team sports. We can say that sportive activities are the most appropriate environment for individual responsibility training.

It is seen that there is no significant difference at p:0,05 level when analyzing the standard deviation and averages of the scores from the individual-social responsibilities scale and the $t$ values of the differences of the scores in terms of sport type variable. In the study conducted by Yıldırım and Özcan, it was determined that there is no significant difference between the social skill levels of the students who do sports and who don't. However, it has 


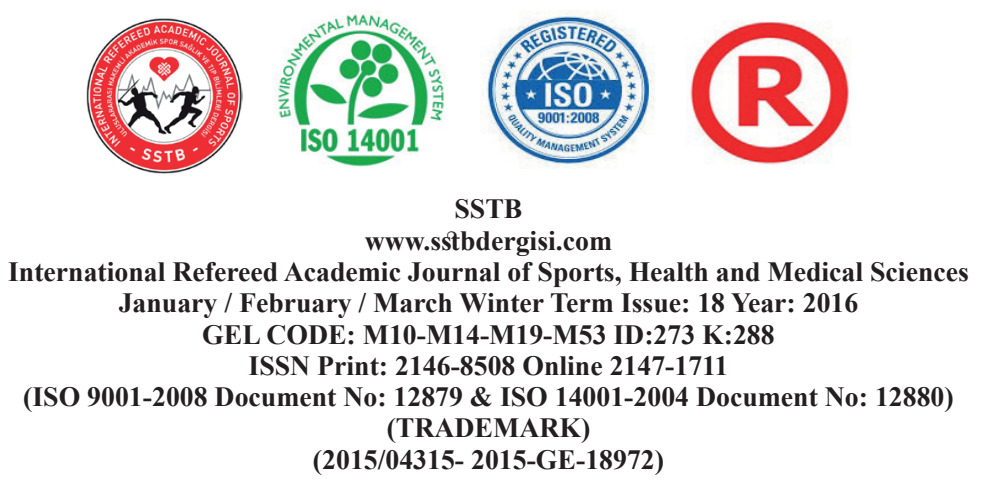

been found that there is a significant difference and the social skill levels of the students who do individual and team sports than those of the students who don't do any sports. As the individual responsibility is at the forefront in the individuals who do individual and team sports, it is evaluated as normal that there is no difference.

It is seen that there is significant difference between the scores from the individual-social responsibility scale and the sports span of the students at p:0,05 level. It has been determined that the average scores of the students who don't do any sports are lower than those of the students who do sports for 2-4 years and 5 years and above. Sports span and individual-social responsibility increase in parallel with each other. Depending on this, sports training span should be evaluated as individual responsibility training span.

It is seen that there is significant difference at p:0,05 level between the scores from the individual-social responsibility scale and the weekly sports span of the students. It has been determined that the average scores of the students who don't do any sports are lower than those of the students who do sports at different times a week. Reynolds et al. (1990) stated that regular physical activities affect life quality and other psychological variables positively and exercises have positive effects on social competence expectations, stress and social factors. The facts that the sports have in its origin such as participating in group activities, orientating to the leader, leading, obeying the rules contributes to the individual to take individual and social responsibility and his personal development.

Depending on these obtained findings, the contribution of the sports to individual, social and personal development should not be ignored. It can be said that the fact that the students utilize the sports opportunities and sports facilities in the school, participate in the activities consciously and steadily, are directed to sportive activities according to their talents and interests can increase their individual and social responsibility levels. In the light of this information, the necessity to ensure that the students participate in sportive activities forms the recommendations part of our study.

\section{References}

C $\ddot{U} C E L O \breve{G} L U, D ., ~(2002)$. For a Life Without Regret Communications Equipment,

\section{Printing, Remzi Bookstore}

DODURGALI, A., (2010). Parental Attitudes in Children and Adolescents Training. Timaş Publications, 2. Printing, İstanbul

DURMUS, A., (2006). Education and Character Development in Children Confi- 


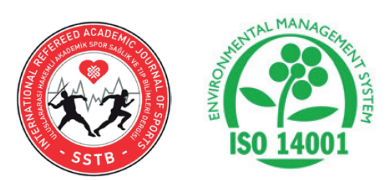

SSTB

www.sstbdergisi.com

International Refereed Academic Journal of Sports, Health and Medical Sciences

January / February / March Winter Term Issue: 18 Year: 2016

GEL CODE: M10-M14-M19-M53 ID:273 K:288

ISSN Print: 2146-8508 Online 2147-1711

(ISO 9001-2008 Document No: 12879 \& ISO 14001-2004 Document No: 12880)

(TRADEMARK)

(2015/04315- 2015-GE-18972)

dence. Nesil Publications, 3. Printing, August, İstanbul

ERASLAN, L., (2011). Development of Individual Social Responsibility Questionnaire. Validity and Reliability Study. Family and Community Education and Cultural Research Journal, 7(24), 81-82

G $\ddot{U} \boldsymbol{V E N}, \boldsymbol{G .}$ Evaluation reviewed and Sports Program in Preschool Education Institutions in Kütahya. Unpublished Master's Thesis, Dumlupinar University Institute of Social Sciences, Kütahya

HAYTA, Ö.Ş., (2005). Responsibility Training Effect of a High School Ninth Grade Students Level of Responsibility Program. Master's Thesis, Uludağ University Institute of Social Sciences. Bursa

LUCKNER, J., (1994). "Developing Independent and Responsible Behaviors in Students Why Are Deaf or Hard Of Hearing." Teaching Exceptional Children, (26-2): 13-17

NELSON, D. B., et all., (2003). Personal Responsibility Map, Oakwood Solutions, Lic

ÖZALP, İ., et all., (2008). Corporate Social Responsibility Perceptions of Faculty of
Economics and Administrative Sciences students on a Study. Anadolu University Journal of Social Sciences. Volume.8 Number. 1

REYNOLDS, K.D., et all., (1990). Psycosocial Predictors of Physical Activity in Adolescents. Previous Medicine, 19(5), 541-551

SMITH, C.T.A., et all., (2007). Post as a Vehicle for Deploying Corporate Social Resposibility. JCC 25. 1-12

TOZLU, N., (1991). Economic Development, Responsibility and Education. Turkish World Research 1. Number. 75

YONTAR, A., et all., (2009). Investigation of Sanctions Used by Teachers Gaining Responsibility. Education and Science Journal. Volume 34, Number 153

\section{ONLINE RESOURCS}

http://webportal.robcol.k12.tr/tr/Egitim/

Ögretim/Haberler (11.08.2015)

Author's Note:This study was presented Orally at 2016 International Conference on Hospitality, Leisure, Sport and Tourism (in Bangkok/Thailand on 19 21 January 2016). 